STUDI

FRANCESI

\section{Studi Francesi}

Rivista quadrimestrale fondata da Franco Simone

168 (LVI | III) | 2012

Varia

\title{
Poésies du non-sens. Tome II: Resveries. Oiseuses, Resveries, Traverses, textes édités, traduits et commentés par Martijn Rus
}

\section{G. Matteo Roccati}

\section{(2) OpenEdition}

\section{Journals}

\section{Édition électronique}

URL : http://journals.openedition.org/studifrancesi/3644

DOI : 10.4000/studifrancesi.3644

ISSN : 2421-5856

Éditeur

Rosenberg \& Sellier

\section{Édition imprimée}

Date de publication : 1 décembre 2012

Pagination : 543

ISSN : 0039-2944

\section{Référence électronique}

G. Matteo Roccati, « Poésies du non-sens. Tome II: Resveries. Oiseuses, Resveries, Traverses, textes édités, traduits et commentés par Martijn Rus », Studi Francesi [En ligne], 168 (LVI | III) | 2012, mis en ligne le 30 novembre 2015, consulté le 08 mars 2021. URL : http://journals.openedition.org/ studifrancesi/3644; DOI : https://doi.org/10.4000/studifrancesi.3644

Ce document a été généré automatiquement le 8 mars 2021.

\section{cc) (†) $\odot$}

Studi Francesi è distribuita con Licenza Creative Commons Attribuzione - Non commerciale - Non opere derivate 4.0 Internazionale. 


\title{
Poésies du non-sens. Tome II: Resveries. Oiseuses, Resveries, Traverses, textes édités, traduits et commentés par Martijn Rus
}

\author{
G. Matteo Roccati
}

\section{RÉFÉRENCE}

Poésies du non-sens. Tome II: Resveries. Oiseuses, Resveries, Traverses, textes édités, traduits et commentés par Martijn RUs, Orléans, Paradigme, 2010 («Medievalia», 74), pp. 158.

1 Après un premier tome consacré aux Fatrasies de Beaumanoir et d'Arras (2005, voir Rassegna, LII, n. 156, p. 637), ce deuxième volume rassemble trois textes: les Oiseuses (ms. BnF, fr. 1588) de Philippe de Remi père, sire de Beaumanoir, également auteur sans doute du premier recueil de fatrasies, et deux œuvres anonymes: les Resveries (ms. fr. 837) et les Traverses (ms. fr. 24432). Ces textes sont apparentés par une forme proche (de norme distiques d'un octosyllabe, ou un heptasyllabe, et un quadrisyllabe) et par leur «non-sens relatif» (p.121) qui ne vise pas l'absurde, mais relève d'un «langage de communion» (p.135), dont le but n'est pas la communication; il s'agit plutôt d'un échange où se manifeste la cohésion du groupe, par des truismes, la référence à un quotidien commun, dans une accumulation de notations indépendantes, vraisemblablement produites par plusieurs intervenants.

2 L'édition est précédée d'un bref examen de la langue; les textes sont accompagnés en regard de notes développées et de la traduction en français moderne au-dessous; en apparat sont indiquées les interventions sur le manuscrit (unique dans les trois cas). Des Réflexions finales (pp. 121-149) suivent, où l'A. donne une présentation générale des textes et où il traite de leur nature, de leur langage et de leur richesse de «notations du 
quotidien» (relatives au monde du travail, aux jeux, à la nourriture, etc., sans oublier maximes populaires et lieux communs). Il justifie également leur datation (début des années 1260 pour les deux premiers, vers 1303 pour les Traverses) et leur localisation (nord-ouest de la France), et il décrit sommairement les manuscrits. La bibliographie (pp. 151-154) termine le volume. 